Kultura
¿ Edukacja

Culture
and Education

文化与教育 
PUBLISHING COOPERATION

Wydawnictwo Adam Marszałek

Wydawnictwo Naukowe GRADO

China Renmin University Press

Uniwersytet w Białymstoku

Uniwersytet Warszawski

Wyższa Szkoła Gospodarki w Bydgoszczy

\section{ademm jparszaleli}

\section{WYDAWNICTWO NAUKOWE}

GRADO
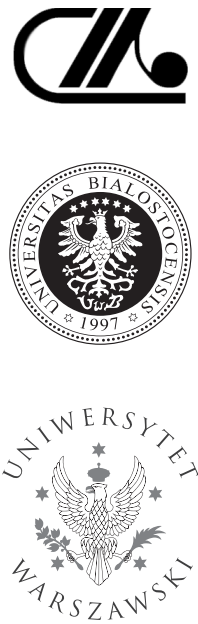
Quarterly 2018, No. 4 (122)

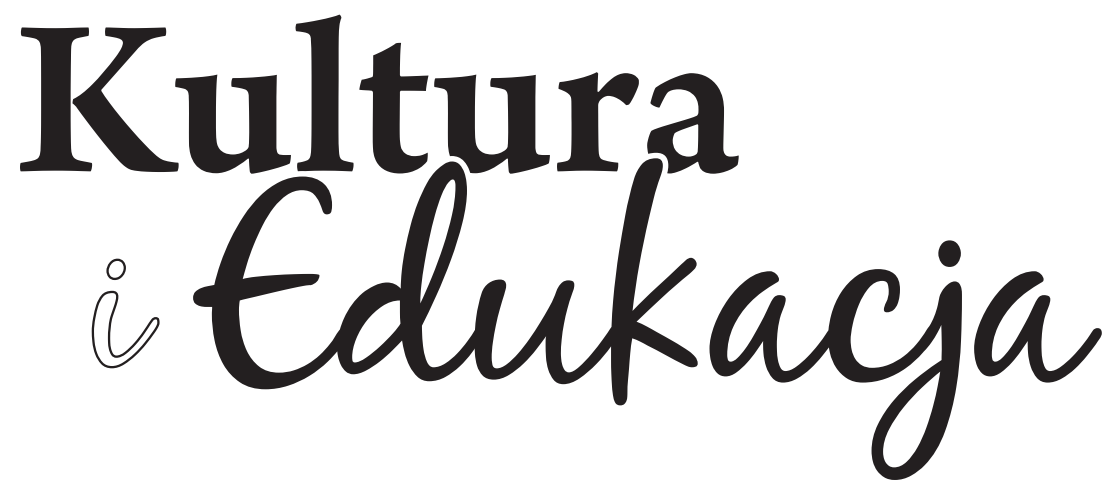

Culture
and Education

文化与教育

edited by

Emilia Żyłkiewicz-Płońska 


\section{ACADEMIC COUNCIL}

Magdalena Bergmann (Bydgoszcz), Susana Coimbra (Portugal),

Peter Cunningham (Great Britain), Zdzisława Dacko-Pikiewicz (Dąbrowa Górnicza), Zenon Gajdzica (Cieszyn), Constantin Geambaşu (Romania), Adam Grzeliński (Toruń), Agnieszka Jeran (Poznań), Mart-Jan de Jong (Holand), Stanisław Juszczyk (Katowice),

Arkadiusz Karwacki (Toruń), Mike Keen (USA), Nino Kemertelidze (Georgia),

Marek Konopczyński (Białystok), Michaił Kurajew (Russia), Tadeusz Lewowicki (Warszawa), Joanna Marszałek-Kawa (Toruń), Zbyszko Melosik (Poznań), Miao Huashou (China), Jerzy Nikitorowicz (Białystok), Joanna Piechowiak-Lamparska (Toruń), Donald Pienkos (USA), Kazimierz Pierzchała (Poland), Vladimir Ploskikh (Kyrgyzstan), Alistair Ross (Great Britain), Mirosław Sobecki (Białystok), Egon Spiegel (Germany), Konrad W. Studnicki-Gizbert (Canada), Krzysztof Szewior (Warszawa), Władysława Szulakiewicz (Toruń),

Mirosław Józef Szymański (Warszawa), Pál Tamás (Hungary),

Marek Walancik (Dąbrowa Górnicza), Anna Wiłkomirska (Warszawa)

EDITORS

Mirosław Sobecki - Editor-in-Chief

Anna Wiłkomirska - Deputy Editor, Dorota Misiejuk - Deputy Editor

Emilia Żyłkiewicz-Płońska - Editor, Secretary

SECRETARIES

Arleta Hrehorowicz, Jia Hanjun, Paweł Jaroniak

THEME EDITORS

Małgorzata Niesiobędzka - psychology, Ewa Owczarz - philology, linguistics, Katarzyna Citko - cultural studies, Alina Wróbel - pedagogy, Arleta Hrehorowicz - law, pedagogy, Małgorzata Halicka - sociology, Elżbieta Czykwin - sociology,

Agnieszka Jeran - sociology, history, Daniel Żuromski - philosophy, cognitive science

PROOFREADING

Damian Kaja

TECHNICAL EDITING

Mieczysław Rabiczko

COVER DESIGN

www.bluz.pl

(C) Copyright by Wydawnictwo Adam Marszałek

(C) Copyright by Wydawnictwo Naukowe GRADO

Toruń 2018

ISSN 1230-266X

Publikacja "Kultura i Edukacja” w języku angielskim, udostępnienie wersji cyfrowej w wolnym dostępie i zabezpieczenie oryginalności publikacji zgodne ze standardem COPE - zadania finansowane w ramach umowy 853/P-DUNdem/2018 ze środków Ministra Nauki i Szkolnictwa Wyższego przeznaczonych na działalność upowszechniającą naukę

Institutional subscription can be ordered in the sections of Kolporter S.A.

throughout Poland. Information at infoline number 0801404044 or on website http://sa.kolporter.com.pl/

„Kultura i Edukacja”, ul. Lubicka 44, 87-100 Toruń, tel. 5666081 60, 5666422 35, w. 26 email: info@kultura-i-edukacja.pl,www.kultura-i-edukacja.pl www.marszalek.com.pl, E-MAIL: info@marszalek.com.pl Drukarnia, ul. Warszawska 54, 87-148 Łysomice, tel. 566783478 


\section{Contents}

\section{ARTICLES - STUDIES}

Staffan Kling, Iwona Sobis

Public Reforms of Swedish Upper Secondary Education, 1991-2017 ................... 9

Janina UszyńsKa-Jarmoc, BeAta Kunat, Monika ŻaK-SKalimowsKa

The Need for Cognition and Meta-learning Competence among Students

of Teacher Education at the University Level

ZENON GAJDZICA

Two Cultures of Inclusive Education of Learners with Disabilities as Two

Borderland Cultures

Mągorzata NiesiobęDzka

Relations between Conspicuous Consumption and Materialism

Maciej Gurtowski, Jan Waszewski

Prejudices behind Algorithms: Automated Surveillance Systems as Tools

of Segregation and Discrimination

Agata Cudowska

The Importance of Creativity in School Culture

Jakub Ali Farhan, Marcin Łukowski, Maciej Perkowski

The Polish-Chinese Economic Intensification in the Context of Legal

Education: Selected Aspects

Barbara Grabowska, Miroseawa Parlak

Image of an Early School Education Teacher in the Eyes of the Third

Grade Pupils - Research Report

Justyna Pilarska

The Potential of Emic Perspective in the Qualitative Inspections

of Everyday Life 
Magdalena BeŁza-GajDZica

Educational Space of a Learner with Disability in the Context

of Infrahumanization of "Outgroups"

Anna Turowska

Career Prospects of Near-to-leave-university Students

Karolina Albińska

Radio as a Transmitter of Culture-specific Knowledge in the Age of Edutainment 190

Justyna CZEKAJEWSKA

Ethical Aspects of the Conscience Clause in Polish Medical Law. 206

Notes on Authors 221 